\title{
THE ANALYSIS OF MORAL VALUES IN DANGEROUS MINDS MOVIE BY JOHN N. SMITH
}

\author{
$1^{\text {st }}$ Anisa Alawiyyah \\ English Education Department \\ STKIP Bina Mutiara, Jawa Barat, Indonesia \\ nisaalawi@gmail.com
}

\author{
$2^{\text {nd }}$ Sri Hastin Oktavi \\ English Education Department \\ STKIP Bina Mutiara, Jawa Barat, Indonesia \\ srihastinoktavia@rocketmail.com
}

\begin{abstract}
This research aims is to find out: The intrinsic element in Dangerous Minds Movie by John N. Smith, The kinds of moral values in Dangerous Movie Minds by John N. Smith, The Cause of the moral value in Dangerous Minds Movie by John N. Smith, The solution of moral values in Dangerous Minds Movie by John N. Smith. The research method used is content analysis and literary psychoanalysis. The subject of the study was Dangerous Movie Minds by John N. Smith. The results of this study include the intrinsic elements in Dangerous Movie Minds by John N. Smith are theme, plot, characterization and background. The kinds of moral values found in this research are honesty, authentic value, self-confidence, moral independence, humility, responsibility, tenacity, reality and crisis, moral faith and courage. These findings suggest that this technique is effective for analyzing the moral values in Dangerous Minds Movie by John N. Smith.
\end{abstract}

Keywords: moral values; dangerous minds; movie; psychoanalytic literature;

\section{INTRODUCTION}

Education is one effort to stimulate, coordinate and guide the continuous growth of teachers in schools both individually and collectively, to be more understanding and more effective in realizing all the teaching functions so that they can stimulate and guide the growth of each student continuously, as well as able and more capable of particple in modern democratic society.

Learners include students or those who get teaching by educators. Factors that learners also important to absorb the lessons and achieve the goal of education for students who are active and diligent in learning activities will affect the percentage of educational success that can be achieved.

Education material this is a factor in the form of material that will be taught by educators and accepted by learners. Educational materials are expected to be a material that is fresh and updated but it also must be easy to digest and interactive. So there are feedback between educators and learners in conducting lessons.

The Method of education is supporting education in conveying the material, method of education can be quickly absorbed well by the students, easy to understand and has the great benefit of science. The environment is also an important factor in the success of an educational destination. Environmental elements that will either support facilities and learning process positively so as to stimulate student interest and given the subject matter can be absorbed and well received.

The target or goal is a goal that will be achieved, by setting a goal then we could have a benchmark of success in running a good education. In this case, the researcher will discuss about the intrinsic elements in the Dangerous Minds movie By John N. Smith, the kinds of moral values in Dangerous Minds movie By John N. Smith, the cause of moral values in Dangerous minds movie By John N. Smith, the solution of moral values in Dangerous Minds movie By John N. Smith and the system Id, ego, superego in Dangerous Minds movie By John N. Smith.

The moral is everything related to what is right and wrong in human behavior is considered right and good by most people in accordance with the standards of behavior that is appropriate to the group or community. The value is a conception of what is desirable and affects a person in determining action on ways and objectives to be achieved will be something that is more important or less important, what is better and less good, and 
what is more right and what is wrong.

So the benefit of learning moral values is able to control personal and compare the morals in society. After comparing several ethical and moral causal can then make choices for themselves, want to be themselves what kind of society.

Movie is a social communication media formed from the merger of two senses of sight and hearing that has a core or theme of a story that revealed many social reality that occurred around the environment where the film itself. According to (Effendi, 1986, p. 239) explained that "Film ini didefinisikan sebagai hasil alat ekspresi budaya dan artistik. Film sebagai media komunikasi merupakan kombinasi dari berbagai teknologi seperti fotografi dan rekaman suara, seni baik seni visual maupun teater, sastra, seni dan arsitektur serta seni musik." Based on the above theory can be concluded that the film is a mass media tool that has seen the nature of hearing (audio-visual) and can reach the audience a lot.

According to Danesi (2010, p.134) explained the types of movie, "Film memiliki tiga kategori utama yaitu film fitur, film animasi, dan dokumentasi. Film fitur adalah sebuah karya fiksi yang selalu berstruktur naratif. Film animasi adalah penggunaan teknik film untuk menciptakan ilusi gerak gambar seri dari dua atau benda tiga dimensi. Dokumenter adalah sebuah karya film nonfiksi yang menggambarkan situasi kehidupan nyata yang terjadi di masyarakat dan setiap individu di dalamnya dijelaskan perasaan dan pengalamannya dalam situasi yang tanpa persiapan, dan langsung di kamera atau pewawancara." Based on the theory above we can conclude that the film is divided into three main categories: feature films, documentation, and the animated film in general known as a cartoon. In this study, the film to be studied belong to the category of documentary or documentation because the documentary is a film that documents a reality and facts. In the documentary there is no fictional story made-up to dramatize scenes throughout the film.

The intrinsic element is the element that builds a movie. It can be said, this element is a component contained in a movie. The parts that build a movie. The theme in a movie is very important in a film industry, not infrequently of the many movie titles in the world give a big impact for the audience. Many directors and producers define themes by name in characters, somewhere or symbolize the feelings in the storyline.

Based on Pratista (2008, p. 9) the theme is "Tema dalam narasi adalah hal yang sangatpenting.Tema tidak dapat terungkap secara langsung tetapi hanya tersirat. Untuk mengetahui tema, seluruh aspek dari sebuah film harus dipahami. Tema bisa diketahui setelah memahami unsur - unsur instrinsik seperti latar, tokoh, dan sudut pandang" Based on the above theory can be concluded that the theme of a story usually implicit (hidden) and can be understood after reading or watching the whole story in which there are figures, grooves, angles and mandate of the story.

Plot is all of series of the events or scene from the start until the end of the movie. Meanwhile, Effendi (1974, p. 165) explained that "Alur drama terdiri dari lima bagian perkembangan, yaitu (1) Pembeberan mula/introduksi, eksposisi;

Penggawatan/komplikasi:

Klimaks/puncak kegawatan; (4) Peleraian; dan (5) Penyelesaian/konklusi. Appearances matter, at this stage, the authors began to introduce the issues to be faced by the main character.

Towards the conflict, the author began to direct the main character enter into a conflict he had previously introduced. Tension, at what stage is the core of a story where the main character was in a very stressful problems. Settlement, after passing the peak of the problem, the authors began to bring the story to the settlement of the problem. Whether the story will have a happy ending, or even vice versa. All of that is a decision of the author.

Characterization is a fundamental aspect in a story, as well as film. Two important elements of a character are his role and personality. These two things are very affecting each other. The role of a character in a movie determines how the movie's 
storyline, without the presence of a role, the story of the film will change.

According to Waluyo (2008, p. 17) explained that "Karakter Dijelaskan dalam tiga dimensi (karakter dimensi) Deskripsi dapat didasarkan pada fisika (tinggi atau pendek, wajah, kurus atau gemuk, jenis kelamin, usia, dll), psikis (hobi, mentalitas, moralitas, ambisi, dll), dan sosial (pekerjaan, agama, kebangsaan, dan lain-lain)." Based on the above theory can be concluded that the character is not only seen on the character of the leaders but also can be seen in psychological terms such as hobbies, mentality, morale and ambition; In physical terms such as tall, short, face, thin or fat, gender, and age and social aspects such as religion professed by the characters, nationality and occupation

Setting is the place the story happened or created. In choosing the setting, the directors have to make some consideration because it also supports the success of the story. Furthermore, Nurgiantoro (2007, p. 17) explained that "Latar adalah segala keterangan, petunjuk, pengacuan yang berkaitan dengan waktu, ruang, dan suasana terjadinya peristiwa dalam cerita. Latar meliputi penggambaran letak geografis (termasuk topografi, pemandangan, perlengkapan, ruang), pekerjaan atau kesibukan tokoh, waktu berlakunya kejadian, musim, lingkungan agama, moral, intelektual, sosial, dan emosional tokoh".

Based on the theory above, we can conclude that the background is a place, a time, as well as the atmosphere of the action figures or events also experienced leaders. setting time corresponding to when the event was narrated, setting the place relating to where the events in the story that happens, then social background related to the behavior of a society that form the habits of life, customs, traditions, beliefs, ways of thinking and the social status of the community in the story.

Presenting entertainment does not mean it cannot give advice or moral message to the audience. Moral or advice messages are conveyed through the characters in the story, so each character portrays certain values.
Another way of conveying the moral message is through the story itself.

According to Siswandarti (2009, p. 44) explained that "Amanat adalah pesan yang ingin disampaikan melalui penulis cerita, baik tersurat maupun tersirat. Berdasarkan hal Amanat adalah pesan yang dibawa penulis akan disajikan melalui belitan peristiwa dalam cerita yang dapat berpikir dan bahan refleksi oleh pembaca (apabila dalam film penonton)". Based on the above theory can be concluded that the type and form of the message or the mandate itself can cover the whole issue of life and life issues, all issues relating to human dignity. Broadly speaking, a matter of life and human life can be divided into the issue of man's relationship with himself, with people, with the environment and with God.

In analyzing a work of literature, researchers can collect data, so it can be searched along with the meaning of data that is organized relationship. So that the analysis of literature can flourish and can be renewed, as well as an understanding of the literature is becoming increasingly varied. Movie also contains subjectivity which is defined as an attitude or opinion of the event, so the perception of reality will depend very much on the maker of the documentary.

Morality is the right attitude and the righteous acts and truly selfless and morality alone can be morally valuable. Moral values can be obtained in the value of morality. Morality also means the suitability of attitudes and deeds with the inner law or norm, which is seen as a duty.

Moral principle of good-bad there and inherent within the individual / person. Although moral it is within the individual, but the moral is a system that exist rules (Ouska and Whellan, 1997). Moral and morality have a little difference, because morality is the principle of good-bad, while morality is the good-bad quality considerations. Thus, the nature and meaning of morality can be seen from the way people who have to comply with the moral as well as running the rule.

Moral comes from the value of something. A value embodied in the form of a person's behavior is what is called moral. So 
a moral is attached to the value of that behavior. Since there is no behavior of a person who is not free of value, only perhaps how far we perceive the values contained in a person's behavior or a group of people who may be in an unclear condition.

Quoting from the book A Parent's Guide In Planting moral values to youth (BKKBN, Jakarta 2002) form of moral values are: (1)Moral values through Faith: Faith in the teaching of religion is to believe the existence of God, the Almighty God and observe all the teachings of his religion. (2) Moral Values Responsible; This means that teens need to know and always do what is in their duties and obligations, and dare to accept the risks of his actions. (3) Moral Values Tenacity; This means that a person must have the willpower and not quickly despair in an effort to achieve its objectives. (4) Moral Values Confidence: It means that a person should be socialized to be independent, not dependent on others, and in every decision taken is always done with all the considerations that are believed.

Based on the sources, we can conclude that this form of moral values, among others, through religious moral values, moral values responsible, moral values tenacity, confidence and moral values. Moral values certainly cannot appear alone without the interference of others, and therefore to be able to understand and live it would not be separated from the assistance of parents and families who are their immediate environment, this mentoring course in the form of guidance and imitation - imitation of parents and other family.

According to Suseno (1987, pp. 142150) attitudes and actions related to forms of moral values, as follows: (1) Honesty, associated with sincerity and uprightness. Suggests that behave towards others, but without honesty is hypocrisy and often toxic. (2) The values of authentic means original. Humans are human beings who live authentic, shows itself in accordance with its authenticity, with the actual personality. (3) The willingness to take responsibility is the first, a willingness to do what it should doing quickly as possible. (4) Moral independence means we never went along with a variety of moral views in our environment, but have always formed the research, and the establishment of its own in act accordingly. (5) Moral courage is the determination and the action to be independent. Courage shows the determination to maintain the attitude that has been believed. (6) Humility is the inner strength to see themselves in accordance with reality. (7) Reality and that is critical to ensure justice and create something that opens the possibility of the state of society is greater than the members to build a more assertive life of misery and happier.

Based on the sources we can conclude that this form of moral values, among others, through religious moral values, moral values responsible, moral values tenacity, confidence and moral values. Moral values certainly cannot appear alone without the interference of others, and therefore to be able to understand and live it would not be separated from the assistance of parents and families who are their immediate environment, this mentoring course in the form of guidance and imitation - imitation of parents and other family.

The cause of the occurrence of moral values caused by several factors are internet media, the mass media, the recent environment, the religious education low, conditions family, emotional intelligence. And the solution of moral values are Make a media of literacy by government as controller of information systems that should be more sensitive and filter what can be accessed by students and all society in cyberspace including accessing porn site and pornography, Income of parents is very influential on the psychological of children, School is a formal education institution that has a very important role in efforts to increase the potential of students and schools have a goal that encourages students to study harder, One's faith is a strong fortress.

Psychology is a discipline that studies mental, thought, and human behavior. This psychology also examines the flow of thought and reasoning behind our behavior and actions, ranging from perceptual thinking, cognitive recognition, and 
interpersonal relationships.

According to Wellek and Austin (2014, p. 81), the term psychology literature has four possible sense. The first is psychological study authors as types or as a person. The second is a study of the creative process. The third type of study and the laws of psychology as applied to literary works. And the fourth study the impact of literature on the reader (reader psychology).

Based on the theory above, we can conclude that a psychological analysis of the literature, especially fiction and drama seems it is not too much because both literary and psychology equally discuss human. Things different are talking about human literature (characters) created by the authors while discussing the psychology of human beings created by God who is real in real life.

Psychoanalysis is a special term in psychology research literature psychoanalytic his art is widely applied in any research literature that uses psychological approach. Generally in every implementation of psychological approaches to literary research drawn from this psychoanalytic theory are only useful and appropriate parts especially those relating to the discussion of human nature and character.

According to Suryabrata (2012, pp. 125127) "Menurut Freud kepribadian terdiri atas tiga sistem atau aspek, yaitu: Id, Ego, dan Super Ego. Id merupakan sumber energi psikis merupakan aspek biologis dan merupakan sistem yang original didalam kepribadian. Ego merupakan aspek psikologis dari kepribadian dan timbul karena kebutuhan organisme untuk berhubungan secara baik dengan dunia kenyataan. Super ego mengacu pada moralitas kepribadian atau aspek sosiologi kepribadian yang merupakan wakil dari nilai-nilai tradisional serta cita-cita masyarakat yang diajarkan dengan berbagai perintah dan larangan"

\section{METHOD}

This research used a qualitative approach with descriptive content analysis method the movie Dangerous Minds by John N. Smith.
Literary approach used is the approach of psychoanalytic literature. So the research is based on the object of literary works are analyzed using psychological theories.

This background of research is the movie entitled Dangerous Minds by John N. Smith, and produced by Don Simpson and Jerry Bruckheimer. This movie tells the story of Louanne Johnson is a former Marine who became an English teacher, Louanne Johnson is now familiar in the know called Mrs John's. He was stranded in PARKMONT High School, became a teacher group of bright young people, with little or no education, who tend to accept failure as the color of his life. Mrs John's pick to win the trust and make changes in their lives.

This movie based on the autobiography My Posse Don't Do Homework by retired U.S. Marine Louanne Johnson who took up a teaching position at Carlmont High School in Belmont, California, in 1989, where most of her students were African-American and Latino teenagers from East Palo Alto, a poverty-stricken, racially segregated, economically deprived city at the opposite end of the school district. Staring Michelle Pfeiffer as Johnson, the film was released to a mixed to mostly negative critical reception, but became a surprise box office success in the summer of 1995 , leading to the creation of a short-lived television series.

Primary data in this research is the dialogue on the film Dangerous Minds by John N. Smith, The loading depiction regarding moral values in the film Dangerous Minds by John N. Smith. Sources Primary data in this study is that the film Dangerous Minds by John N. Smith and produced by Don Simpson and Jerry Bruckheimer. Dangerous Minds was one of the last films of producer Don Simpson. Dangerous Minds was released on August 11, 1995, in the United States. It was an immediate box office success, grossing a total of $\$ 179,519,401$ worldwide.

Based on data analysis techniques in the study entitled "The Analysis of Moral Values In Dangerous Minds Movie by John N. Smith" (A Study of Psychoanalysis Literature) ", are (1) After watching the 
movie Dangerous Minds researchers carefully, researchers classified the intrinsic elements of the film (theme, plot or plot, character, disposition or characterization, background) in the movie Dangerous Minds by John N. Smith. (2) Researchers pay attention to the dialogue or scenes that contain elements Intrinsic in the movie Dangerous Minds by John N. Smith. (3) Researchers understand to the dialogue or scene that contains the forms of moral values in the characters in the movie Dangerous Minds by John N. Smith.

Researcher understand the dialog that contains the cause of moral values in the characters in the movie Dangerous Minds by John N. Smith. (5) Researcher understand and assign a dialog that describes the moral values in the characters in the movie Dangerous Minds by John N. Smith.

Triangulation is a form of data validity checking technique that utilizes something else beyond the data for purposes of comparison and checking data. Because this criterion standard of credibility in qualitative research is also approved for accuracy by the participants studied. There are several criteria that can be used to meet the standards of credibility, namely: Extension of participation, persistence observation, triangulation, peer checking, referential adequacy, negative case studies, and member checking. Researchers did not take the overall form of the above criteria, the researchers only use triangulation techniques , So the researchers collected data as well as test the credibility of the data with data collection and data sources.

\section{RESULT AND DISCUSSION}

The analysis begins with watching a movie, followed by an analysis of moral values, intrinsic elements, causes and solutions of moral values in film and dialogue. The results of the analysis in this study are limited to themes, plot, figure, and background. After the analysis of the intrinsic elements of the film were revealed, and then analyzed the moral value of the film.

\section{The Intrinsic Elements in Dangerous Minds Movie by John N. Smith}

The following are discussed on the themes depicted in Dangerous Minds Movie by John N. Smith are (1) an unyielding and caring educator to his or her students. This theme is a social conflict contained in Dangerous Minds Movie by John N. Smith. This conflict is experienced by the main character is Louanne Johnson. (2) Students who are smart but lack academic ability. This theme is the subject of the Dangerous Minds Movie by John N. Smith. Conflict between the students at Parkmont High School and a new teacher, Louanne Johnson.

The series of events contained in Dangerous Minds by John N. Smith are based on the phases of the flow that have been presented based on relevant theories. Stages of the path, there are Introduction to the initial situation; Disclosure of events; the occurrence of conflict; Peak of conflict; Solution. In Dangerous Minds Movie by John N. Smith, it discussed some of the characters involved in the story. The author describes the main character of white bread Louanne Johnson who is an unyielding and caring teacher of his students.

Michelle Pfeiffer acts as Louanne Johnson or Mrs. Johnson, has white skin, shoulder-length hair with a brownish color, thin body, with a sharp nose, gray eyes, cheerful, and tomboyish. George Dzundza serves as Mr. Hal Griffth, has a fat body, white, small eyes, attention, often smoking and coughing. Courtney B. Vance plays Mr. George Grandey, black, with a thick mustache, thick lips and his people are very hard on rules. Robin Bartlett plays the role of Mrs. Carla Nichols, has white skin, shorthaired brown, sharp-nosed, articulate and has an inevitable nature.

Beatrice Winde acted as Mary Benton, brown-skinned, plump, short-haired, and an angry woman. John Neville plays Waiter in a fancy restaurant called "The Flowering Peach," white-skinned, sharp-nosed, whitehaired, tall, small-eyed and friendly and patient. Lorraine Toussaint plays the role of Irene Robert, black, curly-haired, thick- 
lipped, slightly plump, kind-hearted, and open-minded. Renoly Santiago acts as Raul Sanchero, brown-skinned, black-haired, sharp-nosed, intelligent, but slightly stubborn, irritable, and high self-esteem.

Wade Dominguez plays the role of Emilio Ramirez, white, tall, black-haired, gray-eyed, hard-lipped, powerful, but in fact good and worrisome. Bruklin Harris acts as Callie Robert, brown-skinned, tall, longhaired critic, sharp-nosed, thick-lipped, intelligent, hard-working, and unyielding. Marcello Thedford plays Cornelius Bates, black, plump, thick-lipped, eyed, rarely spoken, jewel-faced and hobbyist wearing a hat. Roberto Alvarez acts as Gusmaro Rivera, white-skinned, slanted-eyed, short-haired, sharp-nosed, and has the same high selfesteem as like Raul Sanchero. Richard Grant acted as Durrel Benton, black, plump, slightly curly-haired, thick-lipped, intelligent, vibrant, and active.

Marisela Gonzales plays Angela, whiteskinned, long-haired curly, sharp-nosed, thinbodied, eloquent, somewhat rude but in good woman. Deshanda Carter plays the role of Tanyekia, fair-skinned, plump, thick-lipped, blond-haired, banged, and often bun. The guy is rude but nice. Rahman Ibraheem plays as Big G, black, tall, thin, thick-lipped, long curly hair, always wearing a hat, like hip-hop dancing and smart people. Desire Galvez plays as Taiwana, fair-skinned, long-haired with brownish color, sharp-nosed, headhungry, and quiet person. Raymond Grant plays as Lionel Benton, black, plump, curlyhaired, and he is his twin brother Durrel Benton and he is a quiet person.

Based on the description and data analysis, as well as research findings, it can be discussed that in Dangerous Minds Movie by John N. Smith there is a place setting, time setting, and cultural setting. The backgrounds are clearly described by the author. In a place setting, the author describes the real places. In the background of time, the author describes the timeliness of the occurrence of an event, and on cultural background, depicted the clarity of an area, culture, or social status and condition of a place or person.
The backgrounds of Dangerous Minds Movie by John N. Smith include the principal room, room 107 which is nothing other than Miss Johnson's teaching class, the Flowering Peach restaurant, the supermarket where Callie Robert works, the library, the police car, the house Callie Robert, Raul Sanchero's house, parking area, amusement park, Durrell house and Lionel.

The time setting contained in Dangerous Movie Minds by John N. Smith is this morning, today, tomorrow, this semester, yesterday, three days, six months, June, week, night, 1960, second lesson, current, 30 days, 29 days, Friday, some days, and summer. The social or cultural setting contained in Dangerous Minds Movie by John N. Smith is the atmosphere in the amusement park, the atmosphere at the Flowering Peach restaurant, the atmosphere at the high school senior Parkmont, room 107.

\section{The Kinds of Moral Values in Dangerous Minds Movie by John N. Smith}

The various moral values discussed in this study include the moral values of honesty is most widely revealed on the character Carla Nichols as many as 3 quotes, Louanne Johnson as many as 3 quotes, Mr. Griffith as much as 1 quotation and Raul Sanchero as much as 2 quotations. The moral value of responsibility are Louanne Johnson as many as 5 quotes, Raul Sanchero as many as 3 quotes, Carla Nichols as many as 2 quotations and Mr. Griffith as much as 1 quote.

Moral courage moral courage in Dangerous Minds Movie by John N. Smith include Louanne Johnson as many as 5 quotes, Mr.Griffith as much as 1 quote, Raul Sanchero as much as 1 quote, Nikki as many as 3 quotes, Emilio ramirez as many as 3 quotes and male Student as much as 2 quotations. Moral independence among others, Callie Robert as many as 3 quotations, Carla Nichols as much as 1 quote, Raul Sanchero as much as 1 quote. Reality and criticism moral values include Louanne Johnson as much as 7 quotes, Carla Nichols as much as 1 quote, Raul Sanchero as much 
as 1 quote, and Emilio Ramirez as much as 1 quote.

The moral values of tenacity in Dangerous Minds Movie by John N. Smith include Louanne Johnson as many as 10 citations, and Callie Robert as much as 1 quote. The moral values of self-confidence in Dangerous Minds Movie by John N. Smith include Carla Nichols as much as 1 quotation, Mr.Griffith as much as 1 quote, Louanne Johnson as many as 5 quotations and Callie Robert 1 quote. The moral values of humility include Mr. Griffith as much as 1 quote, Louanne Johnson as much as 2 quotes, Raul Sanchero as many as 3 quotes, Emilio Ramirez as much as 1 quote. The authentic moral values are Louanne Johnson as much as 2 quotations, Angela as much as 1 quotation and Mr. Grandey as much as 1 quote. Religious moral values such as Louanne Johnson as much as 1 quote, Callie Robert as many as 3 quotes, Emilio Ramirez as much as 1 quotation and Durrell Benton as much as 1 quotation.

\section{The Causes of Moral Values in Dangerous Minds Movie by John N. Smith}

In Dangerous Minds movie by John N. Smith, can be revealed about several causes of moral values of the characters, As for the factors causing the occurrence of moral values, can be put forward as follows internet media, The Environment, Religious education is low, Family condition, Emotional Intelligence.

\section{The Solution of Moral Values in Dangerous Movie Minds by John N. Smith}

In Dangerous Minds movie by John N. Smith, can be revealed several causes of moral values of the characters, As for the solution of moral values are Make a media of fitrasi by government as controller of information systems that should be more sensitive and filter what can be accessed by students and all society in cyberspace including accessing porn site and pornography, Income of parents is very influential on the psychological of children, School is a formal education institution that has a very important role in efforts to increase the potential of students and schools have a goal that encourages students to study harder, One's faith is a strong fortress.

\section{The Discussion of Id System, Ego, Superego in Dangerous Minds Movie by John N. Smith}

Based on the depictions and findings in Dangerous Movie Minds by John N. Smith, it was found that characters who experience an imbalance between Id, ego, and superego. So dominance takes place on Id that gives priority to pleasure then cannot distinguish between good and bad, the ego has to do with adjusting to reality or the environment, Superego associated with the takeover of feelings of behavior from the outside world and into himself.

\section{CONCLUSION}

Movie is an electronic signal to move graphics, images, or text used to combine the flow of images used for entertainment, education, or other purposes. Dangerous Minds Movie by John N. Smith describes the various moral values of the moral value of honesty as much as 9 quotes, authentic moral values as many as 4 quotes, moral responsibility as many as 11 quotations, moral self-efficacy of 5 quotes, moral courage as much as 15 Quotes, humility of 8 quotes, 10 reality quotes and reality, 10 ten quotations, 10 confessions, 8 self-esteem confidence, 6 religious quotes. The depiction of various moral values in Dangerous Movie Minds by John N. Smith is 86 citations.

The moral value that occurs in Dangerous Movie Minds by John N. Smith is caused by several factors, namely technology or internet media and mass media, environment, low religious education, family condition, and emotional intelligence. The solutions found to overcome the causes of moral values include creating a media filtration done by the government as the 
controller of information systems that should be more sensitive and filter anything including porn action and pornography, parental income, in school the ability of teachers Highly demanded and plays an important role in efforts to improve student achievement and success, strengthen one's faith.

The benefit is that the film is essentially an educator teaches how to understand children and can be said to be an educator, a teacher, or a parent who can be regarded as a mentor or caregiver not to be instructors look beyond the bitter environment where pupils / children to socialize. Various parties, such as literary teachers, literary learners, parents, children, literary connoisseurs, literary observers, and others, can better understand and enjoy the literary work. Not only enjoy, but also can hone the ability in various situations and conditions related to the moral value that occurs in a person.

\section{REFERENCES}

BKKBN. (2002). Panduan Orang Tua Dalam Penanaman Nilai-Nilai Moral Kepada Remaja. Jakarta.

Danesi, M. (2010). Pengantar Memahami Semiotika Media. Yogyakarta: Jalasutra.

Effendy, Onong U. (1986). Dinamika Komunikasi. Bandung: Remadja Karya CV

Effendy, Onong U. (1974). Ilmu Komunikasi Teori dan Praktek. Bandung: PT.Remaja Rosdakarya.

Nurgiantoro, B. (2007). Teori Pengkajian Fiksi. Yogyakarta: Gajah Mada University Press.

Ouska, W. (1997). Pengertian Pendidikan Moral. Jakarta: PT. Gramedia.

Pratista, H. (2008). Memahami Film. Yogyakarta: Homerian Pustaka.

Siswandarti. (2009). Panduan Belajar Bahasa Indonesia untuk SMA Kelas $X I$. Yogyakarta: Dinas Pendidikan menengah dan Nonformal Kabupaten Bantul. . Diunduh pada tanggal 15 Juni 2018.

Suryabrata, S. (2003). Psikologi
Kepribadian. Jakarta: PT. Raja Grafindo Pustaka Jaya.

Suseno, Frans M. (1987). Etika Dasar: Masalah-Masalah Pokok Filsafat Moral. Yogyakarta: Karnisius.

Waluyo. (2008). Psikologi Pengajaran. Jakarta: PT. Gramedia.

Wellek, R. and Austin W. (2014). Teori Kesusastraan. Terjemahan Melani Budianta. Jakarta: PT. Gramedia Pustaka Utama. 